\title{
Third molar extraction in middle-aged and elderly patient
}

\author{
Jae-Young Kim \\ Department of Oral and Maxillofacial Surgery, Gangnam Severance Hospital, Yonsei University College of Dentistry, Seoul, Korea
}

\begin{abstract}
J Korean Assoc Oral Maxillofac Surg 2021;47:407-408)
Extraction of impacted third molars is a routine procedure performed by oral and maxillofacial surgeons. However, extractions in middle-aged or elderly individuals are not easy, and there are several factors that need to be considered. These factors include decreased healing potential and the risk of complications increasing with age. In addition, third molars can often be fully or deeply impacted in middle-aged individuals, and pathologic changes, such as cysts, caries, or periodontitis of the adjacent second molar, can develop. Furthermore, the rate of ankylosis and systemic disease increases after middle age. It is considered that these factors acting alone or in combination increase the difficulty of extraction.
\end{abstract}

Key words: Third molar, Tooth extraction, Middle age

[paper submitted 2021. 10. 1 / accepted 2021. 10. 5]

Third molars (or wisdom teeth) develop and erupt in the late teens to the early $20 \mathrm{~s}^{1,2}$. In most cases, the eruption occurs partially due to insufficient space being available for eruption, leading to the development of conditions such as chronic pericoronitis, chronic periodontitis, or dental caries in such persons. Many people undergo third molar extraction in their early 20 s because of these reasons. According to Kautto et al. $^{3}$, the peak age of third molar extraction ranged from 23 to 25 years. Based on insurance data, Eklund and Pittman ${ }^{4}$ reported that most third molars were extracted between the ages of 15 to 25 years, with a peak age of 18 years. Some patients retain their third molars until they reach the age of 40 years or over owing to proper positioning and lack of symptoms. Sometimes, it also depends on the patients' preferences.

However, there are some patients who present to a clinic with pathologic changes such as cysts or tumors surrounding the third molar or with symptoms such as pain and swelling after middle age. They had not undergone extraction due to

\section{Jae-Young Kim}

Department of Oral and Maxillofacial Surgery, Gangnam Severance Hospital, Yonsei University College of Dentistry, 211 Eonju-ro, Gangnamgu, Seoul 06273, Korea

TEL: +82-2-2019-4560

E-mail:kjy810927@yuhs.ac

ORCID: https://orcid.org/0000-0002-9423-438X

(c) This is an open-access article distributed under the terms of the Creative Commons Attribution Non-Commercial License (http://creativecommons.org/ licenses/by-nc/4.0/), which permits unrestricted non-commercial use, distribution, and reproduction in any medium, provided the original work is properly cited.

Copyright (C) 2021 The Korean Association of Oral and Maxillofacial Surgeons. the absence of symptoms with full impaction, improper examination, lack of awareness about the presence of impacted third molars (ITMs), poor experience with previous extractions, or the dentist's explanations that extraction is unnecessary or difficult or that it carries a high risk of complications due to anatomical variations. Extraction of the third molar in middle-aged individuals is relatively difficult, possible attributed to several reasons. Therefore, several factors that need to be considered for extraction.

The healing potential is decreased in older patients, and the risk of complications increases with age ${ }^{5-7}$. Phillips et al. ${ }^{8}$ reported that age is a significant predictor of delayed clinical recovery. It is reported that neurosensory deficit with inferior alveolar nerve injury is related to increased age and that the sensory recovery might be incomplete in older patients, ${ }^{9,10}$.

In addition, third molars can often be fully or deeply impacted in middle-aged individuals. As mentioned above, most patients undergo third molar extractions in their early $20 \mathrm{~s}$. Conversely, there are third molars that have not been extracted until after the age of 40 years, but the tooth was deeply impacted and without symptoms. According to Kim et al. ${ }^{11}$, the average age of the patients is higher in cases with deeply ITMs (level D). There are some patients with completely ITMs on the panoramic view, but a computed tomography shows only coverage by soft tissue without overlying bone. These patients often have calculus on the third molar and severe inflammation of the surrounding soft tissues. Thus, bleeding due to inflammation, along with the deep impaction, 
makes the extraction more difficult.

Furthermore, pathologic changes, such as cysts, caries, or periodontitis of the adjacent second molar, can develop. Terauchi et al. ${ }^{12}$ reported that the average age of onset of dentigerous cysts related to ITMs was $45.9 \pm 13.3$ years. In 2017 , Kim et al. ${ }^{13}$ investigated the development of pathologic conditions in ITMs and the adjacent teeth based on age in Korean patients. They reported that the severity and frequency of pathologic changes in ITMs and second molars due to ITMs increased with age. When a cystic lesion is present, a bony defect approximately the size of the cyst is created, and the area where bone healing should occur increases. Additional treatment is required in cases with lesions occurring in the adjacent second molar, and extraction of the second molar may become necessary in severe cases.

The rate of ankylosis and systemic disease increases after middle age. Baensch et al. ${ }^{14}$ reported a high rate of ankylosis and medical problems in elderly patients. Ankylosis is a common finding during third molar extractions in many middleaged and elderly patients in clinical practice. Comorbidities such as cardiovascular disease or diabetes are more prevalent in elderly individuals; therefore, a multidisciplinary medical consultation is often required.

Not all patients have these problems after middle age, and not all patients require prophylactic extraction of teeth as a preventive measure. However, it is clear that the extraction becomes difficult, or additional surgical intervention might be necessary when the factors mentioned above act alone or in combination.

\section{Author's Contributions}

The manuscript was written by J.Y. K.

\section{Conflict of Interest}

No potential conflict of interest relevant to this article was reported.

\section{References}

1. De Bruyn L, Vranckx M, Jacobs R, Politis C. A retrospective co- hort study on reasons to retain third molars. Int J Oral Maxillofac Surg 2020;49:816-21. https://doi.org/10.1016/j.ijom.2019.10.003

2. Lee SS, Byun YS, Park MJ, Choi JH, Yoon CL, Shin KJ. The chronology of second and third molar development in Koreans and its application to forensic age estimation. Int J Legal Med 2010;124:659-65. https://doi.org/10.1007/s00414-010-0513-x

3. Kautto A, Vehkalahti MM, Ventä I. Age of patient at the extraction of the third molar. Int J Oral Maxillofac Surg 2018;47:947-51. https://doi.org/10.1016/j.ijom.2018.03.020

4. Eklund SA, Pittman JL. Third-molar removal patterns in an insured population. J Am Dent Assoc 2001;132:469-75. https://doi. org/10.14219/jada.archive.2001.0209

5. Chuang SK, Perrott DH, Susarla SM, Dodson TB. Age as a risk factor for third molar surgery complications. J Oral Maxillofac Surg 2007;65:1685-92. https://doi.org/10.1016/j.joms.2007.04.019

6. Bui CH, Seldin EB, Dodson TB. Types, frequencies, and risk factors for complications after third molar extraction. J Oral Maxillofac Surg 2003;61:1379-89. https://doi.org/10.1016/ j.joms.2003.04.001

7. Engeland CG, Bosch JA, Cacioppo JT, Marucha PT. Mucosal wound healing: the roles of age and sex. Arch Surg 2006;141:11937; discussion 1198. https://doi.org/10.1001/archsurg.141.12.1193

8. Phillips C, White RP Jr, Shugars DA, Zhou X. Risk factors associated with prolonged recovery and delayed healing after third molar surgery. J Oral Maxillofac Surg 2003;61:1436-48. https://doi. org/10.1016/j.joms.2003.08.003

9. Kim JW, Cha IH, Kim SJ, Kim MR. Which risk factors are associated with neurosensory deficits of inferior alveolar nerve after mandibular third molar extraction? J Oral Maxillofac Surg 2012;70:2508-14. https://doi.org/10.1016/j.joms.2012.06.004

10. Queral-Godoy E, Valmaseda-Castellón E, Berini-Aytés L, Gay-Escoda C. Incidence and evolution of inferior alveolar nerve lesions following lower third molar extraction. Oral Surg Oral Med Oral Pathol Oral Radiol Endod 2005;99:259-64. https://doi.org/10.1016/ j.tripleo.2004.06.001

11. Kim JY, Yong HS, Park KH, Huh JK. Modified difficult index adding extremely difficult for fully impacted mandibular third molar extraction. J Korean Assoc Oral Maxillofac Surg 2019;45:309-15. https://doi.org/10.5125/jkaoms.2019.45.6.309

12. Terauchi M, Akiya S, Kumagai J, Ohyama Y, Yamaguchi S. An analysis of dentigerous cysts developed around a mandibular third molar by panoramic radiographs. Dent J (Basel) 2019;7:13. https:// doi.org/10.3390/dj7010013

13. Kim JY, Jee HG, Song HC, Kim SJ, Kim MR. Clinical and pathologic features related to the impacted third molars in patients of different ages: a retrospective study in the Korean population. J Dent Sci 2017;12:354-9. https://doi.org/10.1016/j.jds.2017.01.004

14. Baensch F, Kriwalsky MS, Kleffmann W, Kunkel M. Third molar complications in the elderly: a matched-pairs analysis. J Oral Maxillofac Surg 2017;75:680-6. https://doi.org/10.1016/ j.joms.2016.11.021

How to cite this article: Kim JY. Third molar extraction in middle-aged and elderly patient. J Korean Assoc Oral Maxillofac Surg 2021;47:407-408. https://doi.org/10.5125/jkaoms.2021.47.5.407 